- With a modesty that contrasts strongly with the severe language used by Pror. TAIT, he continues :

- To claim priority by insisting on former labors and successes seems to me inadmissible; but nobody will be able to disclaim an essay, printed with its date in a scientific periodical, since even unpublished papers, if they have their date reliably fixed, are deemed admissible for the purpose. 9

"And refraining with considerate carefulness from making a direct or even implied charge of plagiarism, such as Di'HRING made against HELMHOLTZ and TAIT makes against MAYER, he concludes :

- If a scientist has deposited with an Academy or left with the publisher of some periodical an article with its date in a sealed envelope, he can at any time afterwards prove his claim of priority by opening it; the second discoverer is, however, then justified in declaring that he had not and could not have had any knowledge of the contents of that letter; this he cannot say of a firiodical rigularly' published and accessible to czerybody. "1"

Prof. TAlt commits an error in supposing that the original paper by IIOHR was published in Liebig's Annalen der Chemie. This is probably due to the fact that in the Annalen der Pharmacie, of which MIoHr was an associate editor, a short synopsis of his paper appeared under the general heading of a "Re'zue fiir das fahr 1837." (24, I I I) bearing the same title, " Veherdie Natur der iVärme." The charge of plagiarism which TAIT distinctly and deliberately makes on the supposed fact that Mlivek's essay appeared in the same Anmalin where IIonk's original paper was printed, can no longer be sustained ; and one may reasonably hope henceforth to hear of it no more. It should never have been uttered.

In conclusion, it may be stated that, in thus presenting for the first time in the columns of "Scikice:" the complete documentary evidence of Prof. Molle's priority in regard to the discovery of the great principle of the correlation of forces and the conservation of energy, we have been actuated by no other motive than that which underlies all science, viz.: to seck and proclaim the truth and nothing but the truth, and at the same time to do justice to whom justice is due. And no man deserves more to be accorded an honor which he is entitled to than Frifinkici Molle, whose rare genius and masierly mind never betrayed hin into committing such errors of judgment as may be laid at the door of almost every other writer on the subject.

\section{WYANDOTTE GOVERNMENT,}

A Shor S Study of Tribai. Society, Delivered at the BUSTUN MEETING OF TIIF AMERICAN ASSUClatIUN FOR THE. ADVANCl:MENT UF SCIENCl, AUGi'st 1, 1880. BY MIAJOR J. W. Pow Eil., Director, Bureau of Ethnology,

In the social organization of the Wyandottes four groups are recognized, the family, the gens, the phratry, and the tribe.

TIIF FAMII.Y.

The family, as the term is here used, is nearly synonymous with the household. It is composed of the persons who occupy one lodge, or in their permanent wigwams, one section of a communal dwelling. These permanent dwellings are constructed in an oblong form of poles interwoven with bark. The fire was placed in line along

-. Eine Prioritat durch Behauptung fruherer Arbeiten and Erfolge beanspruchen zu wollen, halte ich fitr unzueässig. allein einen in einer wissenschaftlichen Zeitschrift gedruckten und mit dem Datum versehenen Aufsatz geltend zu machen wird Niemand zurlickweisen kiinnen da si gar ungedruckte Aufsätze, wenn sie ein sicheres Ditum haben zu diesem Zwecke zugelassen werden. (s: $8,$.

Hat ein Naturforscher bei ciner Akademie oder bei dem Herausgeber einer Zcitschrift durch einen verschlosernen Kricf l allum senommen, so kann er nachher durch (Offnung des Briefes seine Prioritlltsanspruche beweisen ; der 2weite Entdecker kann aber dann mit Recht sagen, dass er Konnte, das the des Briefes keine Kentiniss hatte und nicht haben

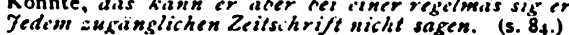

the centre, and was usually built for two families, one occupying the place on each side of the fire.

The head of the family is a woman.

\title{
GENS.
}

The gens is an organized body of consanguineal kindred in the female line. "The woman carries the gens," is the formulated statement by which a Wyandotte expresses the idea that descent is in the female line. Each gens has the name of some animal, the ancient of such animal being its tutelar god. Ep to the time when the tribe left Ohio, cleven gentes were recognized, as follows :

Deer, Bear, Highland Turtle (striped), Highland Turtle (black), Mud Turtle, Smooth Large Turtle, Hawk, Beaver, Wolf, Sea Snakc, and Porcupine.

In speaking of an individual he is said to be a Wolf, a Bear, or Deer, as the case may be, meaning thereby that he belongs to thit gens; but in speaking of the body of people comprising a gens they are said to be relatives of the Wolf, the Bear, or the Deer, as the case may be.

There is a body of names belonging to each gens, so that each person's name indicates the gens to which he belongs. These names are derived from the characteristics, habits, attitudes, or mythologic stories connected with the tutclar god.

The following schedule presents the name of a man and woman in each gens as illustrating this statement :

Indian.

Man of Deer gens

Vivman " "

Man of Bear "

Woman of Bear".

Man of Striped Turtle gens

Woman of Striped Turtle gens

Man of Mlud Turtle gens

Woman of Mud Yan-dăsh-shu-răs Turtle gens

Man of Smooth Large Turtle gens

Woman of Smooth

Large Turtle gens

Man of Wolf gens

Woman. “ “

Man of Snake gens.

IVoman “ „.

Man of Porcupine sens

Woman of pine gens

De-wa-ti-re A-ya-jin-ta A-tu-e-tes Long Claws

Young for her

Ta-ha'-son-ta-rata-se

Tso-we-yuñ-kyn

Sha-yan-tsu-wat'

$H u^{n^{\prime}-d u-c u-t a ́}$

Tsu-ca-cen'

Ha-ro'- $\mathbf{u}^{\mathrm{n}}-\mathbf{y u}$

Yan-di-no

Hu-ta-hu'-sa

Di-je-rons

$11 a^{n} \cdot d u^{\prime}-t u^{n}$

Ke'-ya-runs-kwa

TIIF: PIIRATRY.

There are four phratries in the tribe, the three gentes Bear, Deer, and Striped Turtle constituting the first; the llighland Turtle, Black Turtle, and Smooth Large Turtle the second: the Hawk, Beaver, and Wolf the third; and the Sea Snake and Porcupine the fourth.

This unit in their organization has a mythologic basis, and is chietly used for religious purposes, in the preparation of medicines, and in festivals and games.

The eleven gentes as four phratries constitute the tribe.

Such is the social organization of the Wyandottes.

Each gens is a body of consanguineal kindred in the female line, and each gens is allied to other gentes by consanguineal kinship through the male line, and by affinity through marriage.

To be a member of the tribe it is necessary to be a member of a gens: to be a member of a gens it is necessary to belong to some family; and to belong to a family a person must have been born in the family so that his kinship is recognized; or he must be adopted into a family and become 
ason, brother, or some definite relative; and this artificial relationship gives him tho simue standing an actual relation. ship in the family; in the gens, In the phratry and in the tribe.

Thus a tribe is a body of kindred.

Of the four groups thus described, the gens, the phratry and the tribe constifute the series of organic units; the family or houschold as here described, is not a unit of the gens or phratry, as two gentes are represented in each-the father must belong to one gens and the mother and her children to another.

\section{GOVERNMENT.}

Society is maintained by the establishment of government, for rights must be recognized and duties performed.

In this tribe there is found a complete differentation of the military from the civil government.

CIVII. GoTrR.NIISNT.

The civil government inheres in a system of councils and chiefs.

In each gens there is a council, composed of four women, called Yu-wai-yu-wána. These four women councillors select a chief of the gens from its male members-that is, from their brothers and sons. This gentile chief is the head of the gentile council.

The council of the tribe is composed of the angregatted gentile councils. The tribal conncil, therefore, is composed one-fifth of men and four-tifths of women.

The sachem of the tribe or tribal chief is chosen by the chiefs of the gentes.

There is sometimes a grand council of the gens, composed of the councillors of the gens proper and all the heads of households and leading men-brothers and sons.

There is also sometimes a grand council of the tribe, composed of the council of the tribe proper and the heads of households of the tribe and all the leading men of the tribe.

These grand councils are convened for special purposes.

METHODS OF choosING AND INSTAIIING COUNCH.I.ORS AND chiks.

The four women councillors of the gens are chosen by the heads of households-themselves being women. There is no formal election, but frequent discussion is had over the matter from time to time, in which a sentiment grows up within the gens and throughout the tribe that, in the event of the death of any councillor, a certain person will take her place.

In this manner there is usually one, two or more potential councillors in each gens who are expected to attend all the meetings of the council, though they take no part in the deliberations and have no vote.

When a woman is installed as councillor a feast is prepared by the gens to which she belongs, and to this feast all the members of the tribe are invited. The woman is painted and dressed in her best attire, and the sachem of the tribe places upon her head the gentile chaplet of feathers, and announces in a formal manner to the assembled guests that the woman has been chosen a councillor. The ceremony is followed by feasting and dancing, often continued late into the night.

The gentile chief is chosen by the council women after consultation with the other women and men of the gens. Often the gentile chief is a potential chief through a period of probation. During this time he attends the meetings of the council, but takes no part in their deliberations, and has no vote.

At his installation, the council women invest him with an elaborately ornamented tunic, place upon his head a chaplet of feathers, and paint the gentile totem on his face. The sachem of the tribe then announces to the people that the man has been made chief of the gens, and admitted to the council. This is also followed by a festival.

The sachem of the tribe is selected by the men belonging to the council of the tribe. Formerly the sachemship inhered in the Bear gens but at present he is chosen from the Deer gens from the fact, as the Wyandottes say, that death has carried away all the wise men of the Bear gens.
Tho chief of the Wolf gons is the herald and shoriff of the iribu. Ilo superintends the eroction of the council house, and lias tho care of it. 110 calls tho council tosecther in a formal minner when directed by the sitchem. Ho an. nounces to the tribe all the decisions of the council, and executes the directions of the council and of the sachen.

(ientile councils are held frefuently from day to day and from week to week, and are cilled by the chief whenever deemed necessary. When matters before the council are considered of great importance, a grand council of the gens considerec of
maty be called.

The tribal council is held regularly on the night of the full moon of each lunation and at such other times as the sachem may determine; but extra councils are usually called by the sachem at the request of a number of coun cillurs.

Meetings of the gentile councils are very informal ; but the meetings of the tribal councils are conducted with due ceremony, When all the persons are assembled, the chief of the Wolf gens calls them to order, tills and lights a pipe, sends one putt of smoke to the hearens and another to the earth. The pipe is then handed to the siachem who tills his mouth with smoke, and, turning from left to right with the sun, slowly pufts it out over the heads of the councillors who are sitting in a circle. He then hands the pipe to the min on his left, and it is smoked in turn by each person until it has heen passicel around the circle. The sachem then explains the objece for which the council is called. Each person in the wat and manner he choose's, tells what lie thinks should be done in the case. If a majority of the council is agreed as to action, the sachem doe's not speak, but may simply announce the decision. But in some cases there may be protracted debate which is carried on with great deliberation. In case of a tie, the sachem is expected to speak.

It is considered dishonorable for any man to reverse his decision after having spoken.

Such are the organic elements of the IVyandotte government.

$$
\text { FINCTIONS OF CIVII, GOVKR.MENT. }
$$

It is the function of government to preserve rights and enforce the performance of duties. Rights and duties are co-relative. Rights imply duties, and duties imply rights. The right inhering in the party of the first part imposes a duty on the party of the second part. The right and its corelative duty are inseperable parts of a relation that mist be maintained by government; and the relations which governments are established to maintain may be treated under the general head of rights.

In Wyandotte government, these rights may be classed as follows:

First:-Rights of marriage.

Second:-Rights to names.

Third:- Rights to personal adornments.

Fourth:- Rights of order in encampments and migrations.

Fifth:-Rights of property.

Sixth:-Rights of person.

Seventh:-Rights of community.

Eighth:-Rights of religion.

To maintain rights, rules of conduct are established, not by formal enactment but by regulated usage. Such custommade laws may be called regulations.

\section{MARRIAGE REGCLATION.}

Marriage between members of the same gens is forbidden, but consanguinial marriages between persons of different gentes are permitted. For example, a man may not marry his mother's sister's daughter, as she belongs to the same gens with himself; but he can marry his father's sister's daughter, because she belongs to a different gens.

Husbands retain all their rights and privileges in their own gentes, though they live with the gentes of their wives. Children, irrespective of sex, belong to the gens of the mother. IIen and women must marry within the tribe. A woman taken to wife from without the tribe, must first be adopted into some family of a gens other than that to which the man belongs. That a woman may take for a husband a man without the tribe, he must also be adopted into the family of some yens other than that of the woman. What has been called by some ethnologists endogamy and exog- 
amy, are correlative parts of one regulation, and the $\mathrm{W}$ yandoites, like all other tribes of which we have any knowledge in North America, are both endogamous and exogamous.

Polygamy is permitted, but the wives must belong to different gentes. The first wife remains the hoad of the household. Polyandria is prohibited. A man secking a wife consults her mother, sometimes direct, and sometimes through his own mother. The mother of the girl advises with the women councillors to obtain their consent, and the young people usually submit quietly to their decision. Sometimes the women councillors consult with the men.

When a girl is betrothed, the man makes such presents to the mother as he can. It is customary to consummate the marriage before the end of the moon in which the betrothal is made. Bridegroom and bride make promises of faithfulness to the parents and women councillors of both parties. It is customary to give a marriage feast in which the gentes of both parties take part. For a short time at least, bride and groom live with the bride's mother, or rather in the original houschold of the bride.

The time when they will set up housekeeping for themselves is usuatly arranged before marriage.

In the event of the death of the mother the children belong to her sister or to her nearest female kin, the matter being settled by the council women of the gens. As the children belong to the mother, on the death of the father the mother and children are cared for by her nearest male relative until subsecquent marriage.

\section{NAMr: krialations.}

It has been previously explained that there is a body of names, the exclusive property of each gens. Once at year, at the green-corn festival, the council women of the gens select the names for the children born during the previous year, and the chief of the gens proclains these names at the festival. No person maly change his name, but every person, man or woman, by honorable or dishonorable conduct, or by remarkable circumstance, may win a second name commemorative of deed or circumstance, which is a kind of title.

\section{REGULATIONS OF PERSONAL ADORNMENT.}

Fach clan has a distinctive method of painting the face, a distinctive chaplet to be worn by the gentile chief and council women when they are inaugurated, and subsequently at festival occasions, and distinctive ornaments for all its members, to be used at festivils and religious ceremonies.

\section{RlGQLATIONS OF ORIDER IN HECAMPMINT ANI MILR.THUNS.}

The camp of the tribe is in an open circle or horseshoc, and the gentes camp in the following order, beginning on the left and going around to the right:

Deer, Bear, Highland Turtle (striped), Highland Turtle (black), Mud Turtle, Smooth Iarge Turtle, Hawk, Beaver, Wolf, Sea Snake, Porcupine.

The order in which the households camp in the gentile group is regulated by the gentile councillors and adjusted from time to time in such a manner that the olde'st family is placed on the left, and the youngest on the right. In migrations and expeditions the order of travel follows the analogy of encampment.

\section{PROP'ERTY RIGHTS.}

Within the area claimed by the tribe each gens occupies a smaller tract for the purpose of cultivation. The right of the gens to cultivate a particular tract is a matter settled in the council of the tribe, and the gens may abandon one tract for another only with the consent of the tribe. The women councillors partition the gentile land among the householders, and the household tracts are distinctly marked by them. The ground is re-partitioned once in two years. The heads of households are responsible for the cultivation of the tract, and should this duty be neglected the council of the gens calls the responsible parties to account.

Cultivation is communal; that is, all of the able-bodied women of the gens take part in the cultivation of each household tract in the following manner:
The head of the household sends her brother or son into the forest or to the stream to bring in game or fish for a feast; then the able-bodied women of the gens are invited to assist in the cultivation of the land, and when this work is done a feast is given.

The wigwam or lodge and all articles of the houschold belong to the woman-the head of the household-and at her death are inherited by her eldest daughter, or nearest of female kin. The matter is settled by the council women. If the husband die his property is inherited by his brother or his sister's son, except such portion as may be buried with him. His property consists of his clothing, hunting and fishing implements and such articles as are used personally by himself.

Usually a small canoe is the individual property of the man. Large canoes are nade by the male members of the gentes, and are the property of the gentes.

$$
\text { RICIITS OF PERSON. }
$$

Each individual has a right to freedom of person and security from personal and bodily injury, unless adjudged guilty of crime by proper authority.

\section{CoMmeNITY RIGITS.}

Each gens has the right to the services of all its women in the cultivation of the soil. Each gens has the right to the service of all its male members in avenging wrongs, and the tribe has the right to the service of all its male members in time of war.

$$
\text { RICiHTS OF RELIGION. }
$$

Each phratry has the right to certain religious ceremonies and the preparation of certain medicines.

Each gens has the exclusive right to worship its tutelar god, and each individual has the exclusive right to the possession and use of a particular amulet.

cRIIIS.S.

The violations of rights are crimes. Some of the crimes recognized by the $\mathbf{W}$ yandottes are as follows :
I. Adultery.
2. Theft.
4. Murder.
3. Maiming.
5. Treason.
6. Witchcraft.

A maiden guilty of fornication may be punished by her mother or female guardian, but if the crime is tharant and repeated, so as to become a matter of general gossip, and the mother fails to correct it, the matter may be taken up by the council women of the gens.

A woman guily of adultry, for the first offence is punished by having her hair cropped; for repeated offences her left ear is cut oft

\author{
THFFl.
}

- The punishment for theft is two-fold restitution. When the prosecutor and prosecuted belong to the same gens, the trial is before the council of the gens, and from it there is no appeal. If the parties involved are of different gentes, the prosecutor, through the head of his household, lays the matter before the council of his own gens; by it the matter is laid before the gentile council of the accused in a formal manner. Thereupon it becomes the duty of the council of the accused to investigate the facts for themselves, and to settle the matter with the council of the plaintiff. Failure thus to clo is followed by retaliation in the seizing of any property of the gens which may be found.

\section{MAImixi.}

Maiming is compounded, and the method of procedure in prosecution is essentially the same as for theft.

MURINR.

In the case of murder, if both partics are members of the sime gens, the matter is tried by the gentile conncil on complaint of the head of the household, but there may be an appeal to the council of the tribe. Where the parties belong to different gentes, complaint is formally made by the injured party, through the chief of his gens, in the following manner: 
A wooden tablet is prepared upon which is inscribed the totem or heraldic emblem of the injured man's gens, and a picture writing setting forth the offence follows.

The gentile chicf appears before the chief of the council of the offender, and formally states the offence, explaining the picture-writing, which is then delivered.

A council of the offender's gens is thereupon called and a trial is held. It is the duty of this council to examine the evidence for themselves and to come to a conclusion without further presentation of the matter on the part of the person aggrieved. Having decided the matter among them. selves, they appear before the chief of the council of the aggrieved party to offer compensation.

If the gens of the offender fail to settle the matter with the gens of the aggrieved party, it is the duty of his nearest relative to avenge the wrong. Either party may appeal to the council of the tribe. The appeal must be made in due form, by the presentation of a tablet of accusation.

Inquiry into the effect of a failure to observe prescribed formalities developed an interesting fact. In procedure against crime, failure in formality is not considered a violation of the rights of the accused, but proof of his innocence. It is considered supernatural evidence that the charges are false. In trials for all offences forms of procedure are, therefore, likely to be earnestly questioned.

$$
\text { TRr.Asis. }
$$

Treason consists in revealing the secrets of the medicine preparations or giving other information or assistance to enemies of the tribe, and is punished by death. The trial is before the council of the tribe.

\section{WITCHCRAF"}

Witcheraft is punished by death, stablaing, tomahawking, or burning. Cliarges of witcheraft are investigated by the grand council of the tribe. When the accused is adjudged guilty, he may appeal to supernatural judgenent. The test is by fire. A circular fire is built on the ground through which the accused must run from east to west, and from north to south. If no injury is received, he is adjudged innocent; if he falls into the fire, he is adjudged guilty. Should a person accused or having the general reputation of practising witcheraft become deaf, blind, or have sore eyes, ear ache, headache, or other diseases considered loathsome, he is supposed to have failed in practising his arts upon others and to have fallen a victim to them hinself. Such cases are most likely to be punished.

\section{UIIIAWRY.}

The institution of outlawry exists anong the Wyandottes in a peculiar form. An outlaw is one who by lis crimes has placed himself without the protection of his clan. A man can be declared an outlaw by his own clan, who thus publish to the tribe that they will not defend him in case he is injured by another. But, usually, outlawry is declared only after trial before the tribal council.

The method of procedure is analogous to that in case of murder. When the person has been adjudged guilty, and sentence of outlawry declared, it is the duty of the chief of the Wolf clan to make known the decision of the council. This he does by appearing before each clan in the order of its enc:ampmente, and declaring in terms the crimes of the outlaw and the semtence of outlawry, which mily he either of two grides.

In the lowest grade it is declared that, if the man shall thereafter continue in the commission of similar crimes, it will be lawful for any person to kill him; and if killed, rightfully or wrongfuliy, his clan will not avenge his death.

Outlawry of the highest degree makes it the duty of any member of the tribe who may meet with the offender to $k$ ill him.

MH.ITAKY (INFENMENT.

The management of milicary affairs inheres in the military council and chief. The military council is composed of all the able-bodied men of the tribe; the military chicf is chosen by the council from the Porcupine gens. Each gentile chief is responsible for the military training of the youth under his authority. There is usually one or more potential military chicts who are the close companions and assistants of the chief in time of war, and in case of the death of the chief take his place in the order of seniority. Prisoners of war are adopted into the tribe or killed. To be adopted into the tribe it is necessary that the prisoner should be adopted into some family. The warrior taking the prisoner has the first right to adopt him, and his male or female relative's have the right in the order of their kinship. If no one clatims the prisoner for this purpose he is caused to run the gatumelet, as a lest of his courage.

If at his trial he hehave's manfully, clamints are not wanting, but if he behates disgracefully he is put to death.

\section{FrI.L.WWII())II.}

There is an interesting institution found among the Wyandottes, as among some other of our North American tribes, namely, that of fellowhood. Two young men agree to be perpetual friends to each other, or more than brothers. Each reveals to the other the secrets of his life. and counsels with him on matters of importance, aud de. fends him from wrong and violence, and at his death is chicf mourner.

The government of the Wyandottes, with the social orgamization upon which it is based, affurds a trpical example of tribil fovernment throughout Surth America. Within that area there are several hundred distinct governments. In so great a number there is great variety, and in this variety we find different degrees of organization, the degree of organization being determined by the differentiation of the functions of government and the correlative spercialization of organic elements.

Much has yet to be done in the study of these governments before safe generalizations may be made. But enough is known to warrant the following statement.

Tribal government in North America is based on kinship in that the fundamental units of social organization are bodies of consanguineal kindred either in the male or fernale line: these units being what has been well denominated "gentes."

These "gentes" are organized into tribes by ties of relationship and affinity, and this organization is of such a character that the man's position in the tribe is fixed by his kinship. There is no place in a tribe for any person whose kinship is not fixed, and only those persons can be adopted into the tribe who are adopted into some family with artificial kinship specified. The fabric of Indian society is a complex tissue of kinship. The warp is made of streams of kinship blood, and the woof of marriage ties.

With most tribes military and civil affairs are differentiated. The functions of civil government are in general differentiated only to this extent, that executive functions are performed by chiefs and sachems, bett these chiefs and sachems are also members of the council. The council is legislature and court. Perhaps it were better to say that the council is the court whose decisions are law, and that the legislative body properly has not been developed.

In general crimes are weli defined. Procedure is formal, and forms are held as of such importance that error therein is primia facie evidence that the subject matter formulated was false.

When one gens charges crime against a member of aunother, it can of its own motion proceced only ore retaliation. To prevent retaliation, the ge'ns of the offender must take

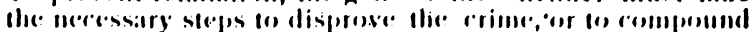
or punish it. The charge once mate: is loced an just and true until it hats heen disproved, and in trial the cause of the defendant is first stated. The anger of the prosecuting gens must he placated.

In the tribal governments there are many institutions, customs, and traditions which give evidence of a former condition in which society was based, not upon kinship. bit upon marriage.

From a survey of the facts it seems highly probable that kinship societv, as it exists among the tribes of North Anerica, has developed from connubial sociely, which is discovered elsewhere on the globe. In fact, lliere are few tribes that secell scarcely to have patssed that indefinite boundary between the two social state's. Philologic research leads to the same conclusion.

Nowhere in North America have a people been discov. 
cred who have passed beyond tribal socicty to national society based on property, i.e., that form of society which is characteristic of civilization. Some peoples may not have reached kinship society; none have passed it.

Nations with civilized institutions, art with palaces, monotheism as the worship of the Great Spirit, all vanish from the priscan condition of North America in the light of anthropologic research.

Tribes, with the social institutions of kinship, art with its highest architectural development exhibited in the structure of communal dwellings, and polvetheism in the worship of mythic animals and nature-gods, remain.

\section{THE GENESIS OF CERTAIN IRON ORES.*}

\section{BY DR. T. STERRY HeNT, LL. D., F.R.S.}

Dr. Hunt began by considering the presence of iron, generally in a ferrous condition, in mineral silicates, in the crystalline rocks, and its liberation therefrom by the sub-acrial decay of these as hydrous ferric oxide. This, as is well known, is, by the agency of organic matter, again reduced to ferrous oxide, which is dissolved in natural waters by carbonic acid or some organic acid, from which solutions it may be deposited either as hydrous peroxide (limonite, etc.,) as carbonate (siderite), is silicate, or as sulphide (pyritc, etc.), in all of which forms iron is found in scedimentary deposits. As regatrls the formation of siderite he described experiments which show that solutions holding five grammes of ferrous carbonate dissolved as di-carbonate in a litre of water, are spontaneously deconposed in close vessels at the ordinary temperature, and deposit two-lhirds of their iron as a white crystalline (hydrated) mono-carbonate, with liberation of carbonic-dioxide. This serves to render more intelligible the reduction and segregation of iron as siderite in earthy sediments, as long since pointed out by W. 13. Rogers, for the ores of the coal-measures.

The intervention of soluble sulphates, and their reduction through organic agency to sulphides, determines the formation of sulphide of iron in sediments. The generation of a bi-sulphide (prrite or marcasitc) wats then discussed, and it was shown that the ferrous mono-sulphide which naturally is first generated, may fix a further portion of sulphur and thus form a more stible compound. One example of this is seen when recently precipitated hydrous ferrous sulphide is brought in contact with a solution of a ferric salt, which takes up a portion of the iron, leaving sulphur free to unite with the undecomposed sulphide, and form therewith a very stable higher sulphide of iron. Fxperiments now in progress lead the writer to believe that sulphur liberated from soluble sulphides mas, in a similar manner, unite with ferrous sulphide, and thus help us to explain the generation of pyrites in nature, in the presence of water, at ordinary temperatures.

The changes of siderite and prrite under atmospheric inthences were next considered. The latter by oxidation viclds, as is well known, ferrous sulphate. Its frequent conversion by sub-arial decay into limonite was conceived to be due to the intervention of water, holding carbonates, which, conjointly with oxvgen, changes it into hrdrous peroxide (limonite), which often retains the form of the prrites. The transformation of carhonate of iron into hidoous peroxide is a familiar fact.

Limonite ores mav thus be produced in three wass. They are sometimes formed he the peroxidation and precipitation of dissolved fertous salts, as in the so-tilled hogores: but more frepluently from the alterattion in sifu of deposits of pyrite or of siderite. Such are the limonites which mark the outcrops of beds or veins of prites in the decaved crestalline recks of the Blue Riclge. The similat ores found in the decared Taconic sehists of the great Appalachian valley can he shown to he die in some cases to the alteration of included pyritous masses, and in others to the alteration of similar missses of siderite, both of which are found in the unalfened faconic rocks, as, indered, at various other horigons in the geolongical series.

If we take the specitic gratrity of protes : at 5.0, we shall find that its complete conversion into a limmonite of sp. gr.

- Read before the A. A. A. S., Boston, 1880.
4.0 would be attended with a contraction of only 2.7 hundredths, while if the limonite have a sp. gr. of 3.6 , there would be an augmentation of $10.7 \mathrm{p}$. $\mathrm{c}$. With siderite of sp. gr. 3.6, on the contrary, its conversion into limonite of the same density would result in a contraction of $19.5 \mathrm{p}$. $c$., and into lemunite of sp. gr. 4.0 to a contraction of $27.5 \mathrm{p}$. c. The evidences of this contraction may be seen in the struc. ture of the limonite derived from siderite. The process operates from the surface of the masses, often resulting in the production of geodes. Their structure will generally serve to distinguish the sideritic from the pyritic limonites.

These differences were illustrated in the history of various iron ores in the Appalachian valley, and it was further pointed out that the pyritic limonites, other circumstances being equal, should be freer from phosphorus than those derived from siderite, since the native carbonates almost always contain phosphates, from which pyritous deposits are comparatively free. The source of limonites thus becomes a question of importance to the metallurgist. In conclusion it wus pointed out that deposits of manganese ores are, in some cases at least, grenerated by the alteration in situ of manganous carbonates, by a process analogous to that by which limonite is prodiced from siderite.-

\section{MICROSCOPY.}

NEW CEILL FOR OPACUE OBJECTS.

I desire to call the attention of the microscopists and preparers of objects generally to the new rubber cell for opaque slides, recently devised by me. A considerable experience in mounting opaque slides during the past few years has convinced me that much of the labor incident to it could be avoided, if a cell of suitable material and shape could be produced at a nominal cost. This, I think, has now been attained, and I take pleasure in submitting one for which I claim convenience, cheapness, and general utility. With it the amateur can produce a slide fully as perfect, and with as great a degree of neatness as can the professional. The cell is of hard rubber, highly polished, and of attractive shape; the base is solid, thus giving a black back-ground of rubber; around the top is a ledge fitted to reccive a one half inch cover glass; this, being secured by a little shellac or any similar cement, completes the mounting. The cell may be attached to a glass slip by any cement, before or after preparation. Foi exchanges it offers.superior advantages, inasmuch as the cell, with objects enclosed, may be sent through the mails independent of the glass slips, the recipient attaching them. In this way a saving is made in postage, and no risk of loss by slips being broken in transit.

They will solve the problem which often perplexes the student or collector who is crowded for cabinet room. Many objects lor future reference may be mounted in this simple cell, numbered and put away without a slide, a cabinet drawer holding two hundred of them, while but forty siides could be accomodated in the same space.

The above sectional view conveys a good idea of its shape, the dotted line indicating the position of the thin glass cover.

1 have made arrangements to have them supplied by the following firms at thirty cents per dozen, five cents extra on single dozens to cover cost of postage and box, and they may be obtained from the parties mentioned below or from the subscriber. In remitting small sums three cent postage samps mav be used.

(iku. S. Wooman, No. 116 Fulton St., New York: Jas. W. Quen \& Co., (Vhestnut St., Philadelnhia; Bat'sch \& DR.A.stifitr, Arcade, Rochester, N. Y.; IV. H. Bthlock, No, 126 So. Clark St., Chicigo, Ills.

In conclusion I would add that I have had these rubber cells prepared without regard to any pecuniary gain to mrself, hoping they may prove an aid in those engaged in microscopical research.

\section{H. F. ATwoon,}

No. 50 Hamilton Place, Rochester, N. Y.

[We have seen a sample of Mr. Atwood's rubber cell, and consider it a very perfect arrangement for opaque objects, - En).] 